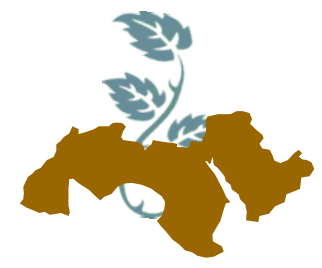

\title{
MODIFICATION AND PERFORMANCE OF DEVICE FOR TESTING THE DIESEL ENGINE INJECTOR
}

\author{
Mayada E. Abdel Razek ${ }^{1}$, Moustafa ${ }^{2}$ M.M., Baiomy ${ }^{3}$ M.A. \\ and Abdel Galil ${ }^{2}$ A.
}

1- Agric. Engineering Sector, Ministry of Agric., Dokki, Giza, Egypt

2- Agric. Eng. Dept., Fac. of Agric., Ain Shams Univ., P.O. Box 68, Hadayek Shobra 11241 , Cairo, Egypt

3- Bio-Engineering Dept., Agric. Engineering Research Institute, Agric. Research Center, Dokki, Giza, Egypt

Keywords: Injection pressure, Fuel consumption, Injector tester, Manual tester, Mechanical tester

\section{ABSTRACT}

There are many devices to test the injectors of a diesel engine, but most of it is operating manually, maintenance and repair centers mostly have used the manually device which depended on the hand of operator to operate it therefore there are inaccuracies in tests. The injector tester device was modified from manual operation to mechanical operation to achieve the uniformity of the injection pressure during the injector test, install of reading, save time and accuracy of testing. Injector tester before the modification was consisted of small fuel tank, pump, pressure gauge, handle pumping and connecting tube. The injector tester device after the modification was consisted of main frame, fuel tank, injection unit, power transmission and measuring table. From the experiments the fuel consumption was increased with injector tester device before modification than device after modification that with three different injectors due to the regularity of the motion in the mechanical device, but the manual device that is dependent on operator and the irregularity of motion which cause irregularity of pressure. Also, the fuel consumption was decreased with injectors' faults. This is indicating of accuracy reading pressure with the modified devices compared with the device before modified. The results indicated for the important factors which effect on the regularity of injection pressure during the injector testing. The injection pressure for modifying tester device was 175 bar and fuel consumption was $0.73 \mathrm{~L} / \mathrm{h}$. The injection pressure and fuel consumption for tester device before modification were 210 bar and $4.73 \mathrm{~L} / \mathrm{h}$ respectively. The rate of reducing can be concluded by using the modified tester device for the injection pressure was 1:0.83 and for fuel consumption was 1:0.155 as compared with the manual tester.

\section{INTRODUCTION}

There are many devices to test the injectors of a diesel engine but most of it are operating manually. The centers of maintenance and repair the injector are using the manual device which depend on the operator hand therefore the test results are inaccurate. Some difficulties problems were occurring during operation the diesel engine caused of reducing efficiency. The most important problem is disabling injector of the diesel engine to be out of the service which causing several phenomena as: - 1- difficult of starting, 2- irregular of engine speed, 3- emission of black and white exhaust Which are produced from Low injection pressure, Occurrence of the process of leakage during the injection process and Occlusion injector nozzles leads to a change in the form of fuel cone. The main objective in the present study is modifying tester device to be suitable the injector of diesel engine. Diesel water pumps are more spreading in Egypt. There are many diesel engine pumps up to $(188,6382)$. The Kerloscar types are represent $22 \%$ from the total water pumps in Egypt (Economic Affairs Sector, 2015). The aim of this study is to investigate some operational factors relevant the modification of hand-operated injector tester device to be suitable for the Egyptian main tenancies and repair centers. 
Khair and Jääskeläinen, (2013) reported that the main functions of diesel system are injection timing control, atomization, bulk mixing \&air utilization, injection quality control. Lechner et al (2005) stated that a low flow rate, $60^{\circ}$ degree spray cone angle injector nozzle, along with optimized Exhaust gas recirculation rate and split injection strategy can reduce engine-out NOx (nitric oxides) by $82 \%$ and particulate matter by $39 \%$, at the expense of a modest increase (4.5\%) in fuel consumption. Bashirnezhad et al (2008) concluded that the fuel spray cone angle has significant impact on flame structure and temperature profiles. The maximum temperature of the flame is increased with the fuel spray angle increased. The result showed the nearly complete dissociation of the fuel is dependent of fuel spray cone angle. Also spray angle has a strong effect on the soot volume fraction. The online measurement of the soot volume fraction exiting the furnace shows to increase the fuel spray cone angle decrease soot volume fraction exhaust from the furnace. The maximum soot volume fraction has occurred in spray cone angle $60^{\circ}$ although in this spray cone angle the soot exit from furnace is minimized. The complete furnace simulation shows large soot volume fraction gradients in the axial and radial direction. Both the numerical and experimental results show that the peak value of soot and is location in the furnace depend on the fuel spray cone angle. Lee and Park (2002) reported that the diesel engine emissions and combustion characteristics are influenced by the dissolution of the fuel nozzle and injection pressure and other factors to improve the air-fuel mixture. Heywood (1988) said that if the spray is too long, it could impinge on and wet the piston wall, leading to combustion instability, the reduction of engine efficiency and increase of exhaust emissions, particularly unborn hydrocarbons and particulates. Park et al (2011) explained that too short a spray would provide insufficient mixing between the injected fuel and the available air, which then causes an increase in the equivalence ratio in the combustion chamber. Svrcek et al (2010) observed that fuel spray characteristics have been studied extensively, as certain spray characteristics have been shown to facilitate the combustion process. Three main aspects of fuel spray characteristics are reviewed: Cone angle, spray length and droplet size distribution. Bell, (1996) stated that the injectors should be checked by a mechanic with an injector tester at intervals of about 1000 hours, but this period will vary to be different engines.

\section{MATERIALS AND METHODS}

The injector tester device was modified from manual operation to mechanical operation to achieve the uniformity of the pressure during the injector test, install of reading, save fuel consumption during test time and accurate of testing.

\section{Injector tester Device before modification}

Injector tester before modification was as shown in Fig. 1. It consists of:

1- Small fuel tank :It is made from plastic.

2- Pump: it is responsible for pumping diesel fuel into the injector which is withdrawing fuel from the tank and push to the injection.

3- Pressure gauge: It is responsible for measuring the required operation pressure.

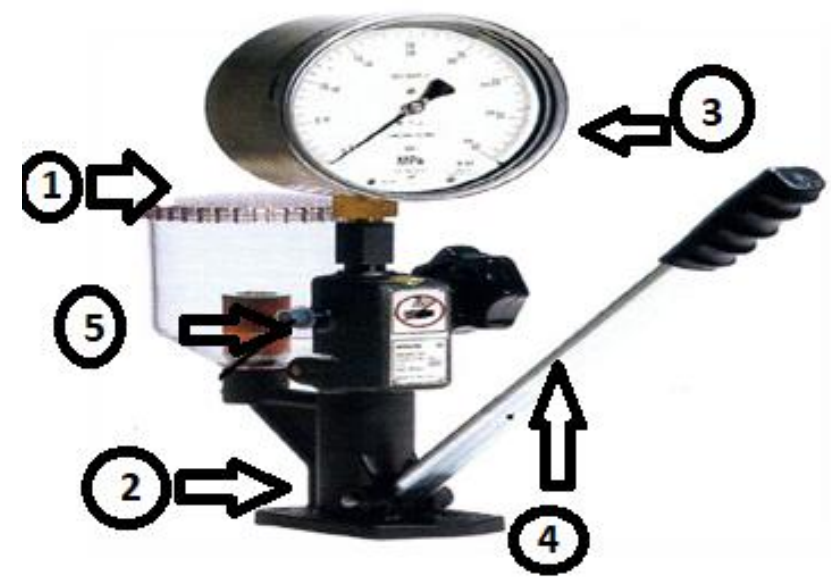

Fig. 1. Injector tester before modification 
4- Handle pumping: It is moving upward and downward by operator and resulting pressure is used to spray fuel through the injector.

5- Connecting tube: It is connected to the injector and varies according to the injector size.
Modification and construction of the injector tester device of diesel engine

The injector tester device after the modification was fabricated locally. The main assembly of device is as shown in Fig. 2 and 3.

The injector tester device after the modification was consisted of the main following unit:
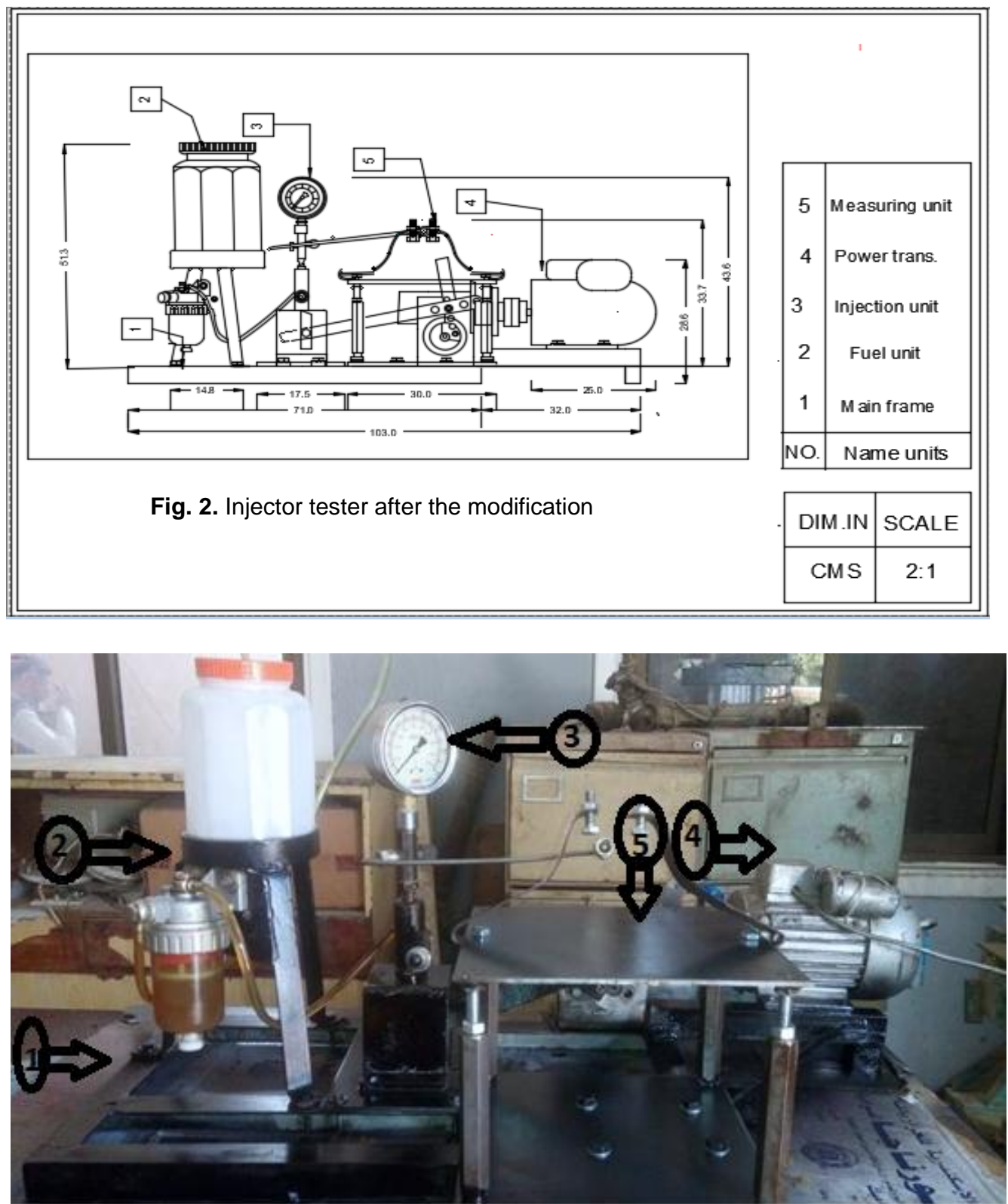

Fig. 3. Injector tester after the modification 


\section{1- The main frame}

The main frame was fabricated from steel angle of $<50 \times 50 \times 5 \mathrm{~mm}$. It consisted of two parts. The dimensions of the first part was $71 \mathrm{~cm}$ long and 40 $\mathrm{cm}$ width while the dimensions of the second part was $36 \mathrm{~cm}$ long and $21.9 \mathrm{~cm}$ width.

\section{2- The fuel tank}

It was fabricated from plastic. The responsibility of the fuel tank was supplying fuel to the pump and injection this quantity to the device test. The tank has a capacity of 4 liters. Transparent filter is out under the tank to move the fuel through it .It holds on a three-legged of iron holder that fixed with the main frame by three bolts.

\section{3- The injection unit}

The injection unit was responsible for pumping the fuel. It consists of (1) The Kerloscar injection pump (8 horsepower) (2) lever to move the piston of pump up and down to spray the fuel out the injector under high pressure through three nozzles (3) pressure gauge (Glycerin Filled Pressure Gauge): it was installed on the top of pump to measure the pressure during the test.

\section{4 - The power transmission:}

The power transmission consists of (1) electric motor. It the responsibility of the power in the device (2) small gearbox was connected to the motor by cobbling and another connects to the lever. It is reducing the rpm from $1400 \mathrm{rpm}$ to $58 \mathrm{rpm}$.

Table 1. The specifications of the electric motor

\begin{tabular}{|c|c|}
\hline Type & YL802-4 \\
\hline Power & $1 \mathrm{HP} / 0.75 \mathrm{~kW}$ \\
Speed & $1400 \mathrm{rpm} / \mathrm{min}$ \\
Established & Made in China \\
\hline
\end{tabular}

Table 2. The specifications of Gearbox

\begin{tabular}{|c|c|}
\hline TYPE & S040KN-B14-11-1 \\
\hline NO. & 14395529 \\
Speed reduction & $25 / 1$ \\
Established & Germany \\
\hline
\end{tabular}

\section{5- Measuring table}

It consists of a four-legged holder. It is installed with the main frame by screws. The upper surface of the holder is fabricated from square sheet metal of $250 * 250 * 3 \mathrm{~mm}$. The injector is installed above the square sheet metal by two flat irons $300^{*} 30$ * $10 \mathrm{~mm}$ which installed with the upper surface of the holder.

The test paper is put on the upper surface of the holder (square sheet metal) to receive fuel from the injector as form of spray to simulate the injector in the engine.

\section{Methods}

Measurements were carried out on the injector diesel of the pump water machine as follows:

Comparison of the pressure gauge type on the injector tester device before and after modification

The pressure gauge on the modified injector tester was calibrated with the injector tester before modified at the local workshop. The pressure gauge on the modified device was replaced to glycerin pressure gauge because the pressure gauge before modification has high fluctuation rate and instability the pointer when reading the pressure unit.

\section{Evaluating the injector tester}

Laboratory experiments will be conducted to evaluate the developed injector tester device compared to the device before modification at different three injectors: first injector was standard injector specifications geometry of injector nozzle as shown Fig. (4), Second injector was not adjust pressure and Third injector was bad injector. 


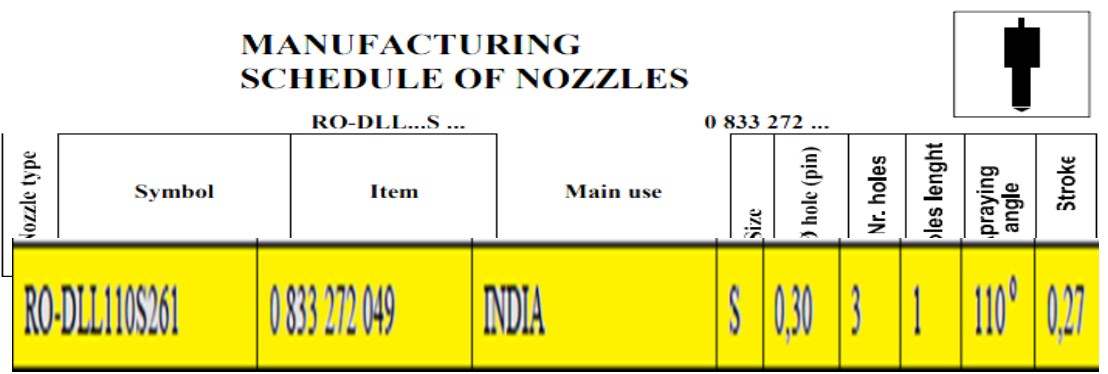

Fig. 4. Specifications geometry of injector nozzle standard

The experiments were run in terms of:

\section{1- Fuel consumption}

Measurement of fuel consumption was replicated three times per each injector from the three injectors which mentioned. All duplicators were taken by graduated cylinder listed with the time calculated by the stop watch. Each injector was installed on 50 injection syringes with the device before and after the development the average of fuel consumption was calculated by the equation (1) and (2).

Average fuel consumption $=$

$$
\begin{aligned}
& \frac{\text { fuel cons. } 1+\text { fuel cons. } 2+\text { fuel cons. } 3}{\text { number for cons. }}=\mathrm{ml} / \mathrm{sec} \\
& =\frac{\text { average fuel cons } . \times 60 \times 60}{1000}=l / h
\end{aligned}
$$

\section{2- Injection pressure}

Pressure gauge (manometer) was used to measure the pressure of injector tester before and after modified. Two different types of manometer were used in these experiments.

The first gauge: The distance between the inserted surface and the outer glass pan is empty (normal manometer). When measuring, the pointer moves up and down and does not stabilize.

The second gauge: The distance between the inserted surface and the outer glass section is filled with glycerin (glycerin manometer). The pointer moves upward when measured consistently and holds at the highest pressure.

The measurement of pressure was replicated three times per each injector from the three injectors which mentioned. The measurement of pressure was running on the injector tester before modification (Atlas workshop) and after modification in Agricultural Engineering Research Institute (AEn$\mathrm{RI})$.

\section{RESULTS AND DISCUSSION}

Effect of the pressure gauge type on the injector tester device

The pressure measurement with the injector tester before modification by (normal manometer) was variable (210 bar). It means that it is not fixed. When used glycerin manometer instead of normal manometers the reading of the pressure was fixed on 175 bar. Also the pressure was 175 bar with the injector tester after modification which use glycerin manometer.

\section{Fuel consumption}

The main results were got of the fuel consumption for the injector tester before and after modification on the three different injectors. The results were different with three injectors and also different with device before and after modification as shown in Table (3).

Table 3. Fuel consumption of three different injectors with the injector tester before and after modification

\begin{tabular}{|c|c|c|}
\hline Injector & $\begin{array}{c}\text { Fuel consumption } \\
(\mathrm{L} / \mathrm{h}) \\
\text { before } \\
\text { modification }\end{array}$ & $\begin{array}{c}\text { Fuel consumption } \\
(\mathrm{L} / \mathrm{h}) \\
\text { after } \\
\text { modification }\end{array}$ \\
\hline Injector & 4.48 & 0.73 \\
standard & 4.41 & 0.73 \\
Injector & 5.29 & 0.73 \\
not adjust & 3.51 & 0.58 \\
pressure & 3.92 & 0.60 \\
& 4.18 & 0.60 \\
Bad injector & 4.30 & 0.55 \\
& 4.35 & 0.58 \\
& 4.98 & 0.51 \\
\hline
\end{tabular}


In the previous table the comparison between the injector tester before and after modification with three different injectors was as follow:

1- Standard injector: The fuel consumption in the device before the modification was different in the three readings. The three replicates of readings were $4.48,4.41,5.29 \mathrm{~L} / \mathrm{h}$, respectively and the average was $4.73 \mathrm{~L} / \mathrm{h}$. But the fuel consumption of the device after the modification was fixed in three replicates of readings. It was $0.73 \mathrm{~L} / \mathrm{h}$.

2- Injector was not adjust pressure: The fuel consumption before modification were $3.51,3.92$, $4.18 \mathrm{~L} / \mathrm{h}$ respectively and the average was $3.87 \mathrm{~L} / \mathrm{h}$. But the fuel consumption after the modification was approximately. It's were 0.58 , $0.60,0.60 \mathrm{~L} / \mathrm{h}$ and the average was $0.59 \mathrm{~L} / \mathrm{h}$.
3- Bad injector: The fuel consumption before modification were $4.30,4.35,4.98 \mathrm{~L} / \mathrm{h}$, respectively and the average was $4.54 \mathrm{~L} / \mathrm{h}$. But the fuel consumption after the modification was approximately. It's were $0.55,0.58,0.51 \mathrm{~L} / \mathrm{h}$ and the average was $0.55 \mathrm{~L} / \mathrm{h}$.

From previous results show that the fuel consumption was increased with an injector tester before modification than device after modification with three different injectors. This is due to the regularity of the motion of the piston in the mechanical device, but the manual device that is dependent on the operator and the irregularity of motion which cause irregularity of pressure, as shown in Fig. (5). Also, the fuel consumption was decreased with injectors faults (2 and 3 ).

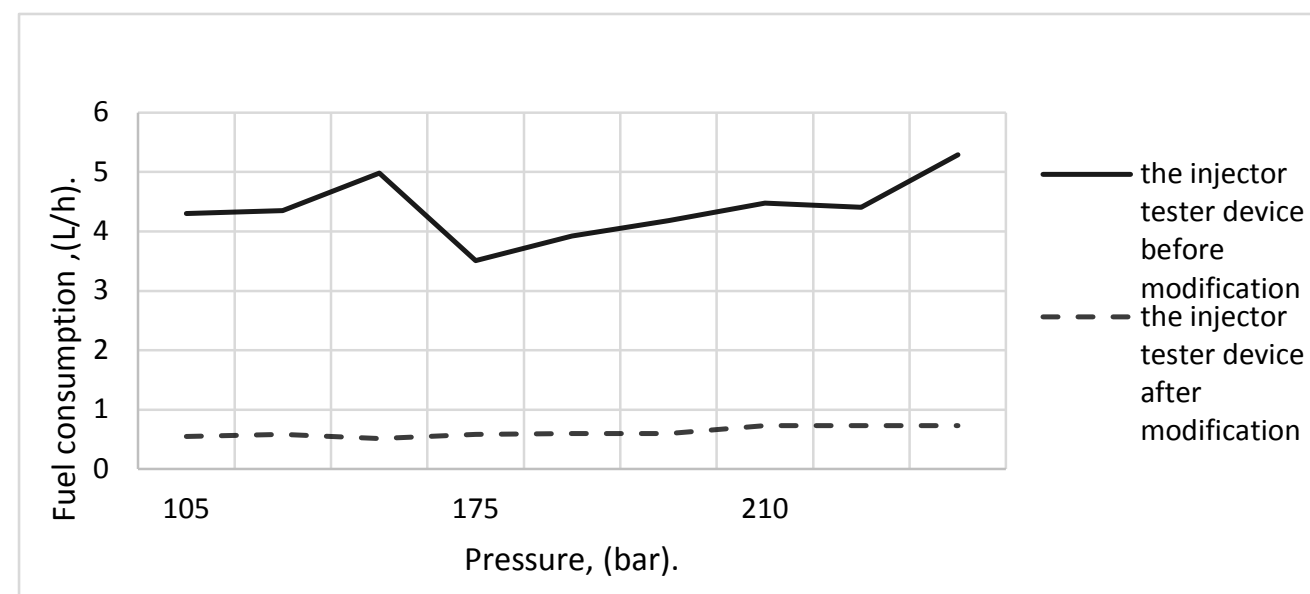

Fig. 5. Fuel consumption with injector tester before and after modification

\section{2- Injection pressure}

The main results were getting of the injection pressure for the injector tester device before and after modification on the tree different injector. The results were different with three injectors and also different with device before and after modification as shown in Table (4).

4- In this case the pressure was measured for three different injectors with two different devices by injecting 50 injections with each test and measure the duration time for each 50 injection. The results were as follows:

5- Standard injector: The pressure with the device before the modification was 210 bar and it was 175 bar after modification.
6- Injector was not adjust pressure: The pressure with the device before the modification was 175 bar and it was 130 bar after modification.

7- Bad injector: The pressure with the device before the modification was 105 bar and it was 100 bar after modification.

8- From previous results show that the pressure was increased with an injector tester device before modification than device after modification with three different injectors this is due to the regularity of the motion in the mechanical device but the other device that is dependent on the operator and the irregularity of motion which cause irregularity of pressure.

9- Also the pressure was decreased with injectors faults $(2,3)$ than stander injector (1) as shown in Fig. (6). 
Table 4. Injection pressure with injector tester before and after modification

\begin{tabular}{|c|c|c|}
\hline Injector & $\begin{array}{c}\text { Injection } \\
\text { pressure } \\
\text { (bar) } \\
\text { before } \\
\text { modification }\end{array}$ & $\begin{array}{c}\text { Injection } \\
\text { pressure } \\
\text { (bar) } \\
\text { After } \\
\text { modification }\end{array}$ \\
\hline $\begin{array}{c}\text { Injector standard } \\
\text { Injector not adjust } \\
\text { pressure } \\
\text { Bad injector }\end{array}$ & 210 & 175 \\
\hline
\end{tabular}

10- Different pressure between device before and after modification is due to the type of manometer with different two injector tester device. The first gauge: The distance between the inserted surface and the outer glass pan is empty (normal gauge). When measuring, the pointer moves up and down and does not stabilize. The second gauge: The distance between the inserted surface and the outer glass section is filled with glycerin (glycerin gauge). The pointer moves upward when measured consistently and holds at the highest pressure.

11- This is indicating of accuracy reading pressure of the modified compared with the device before modified.

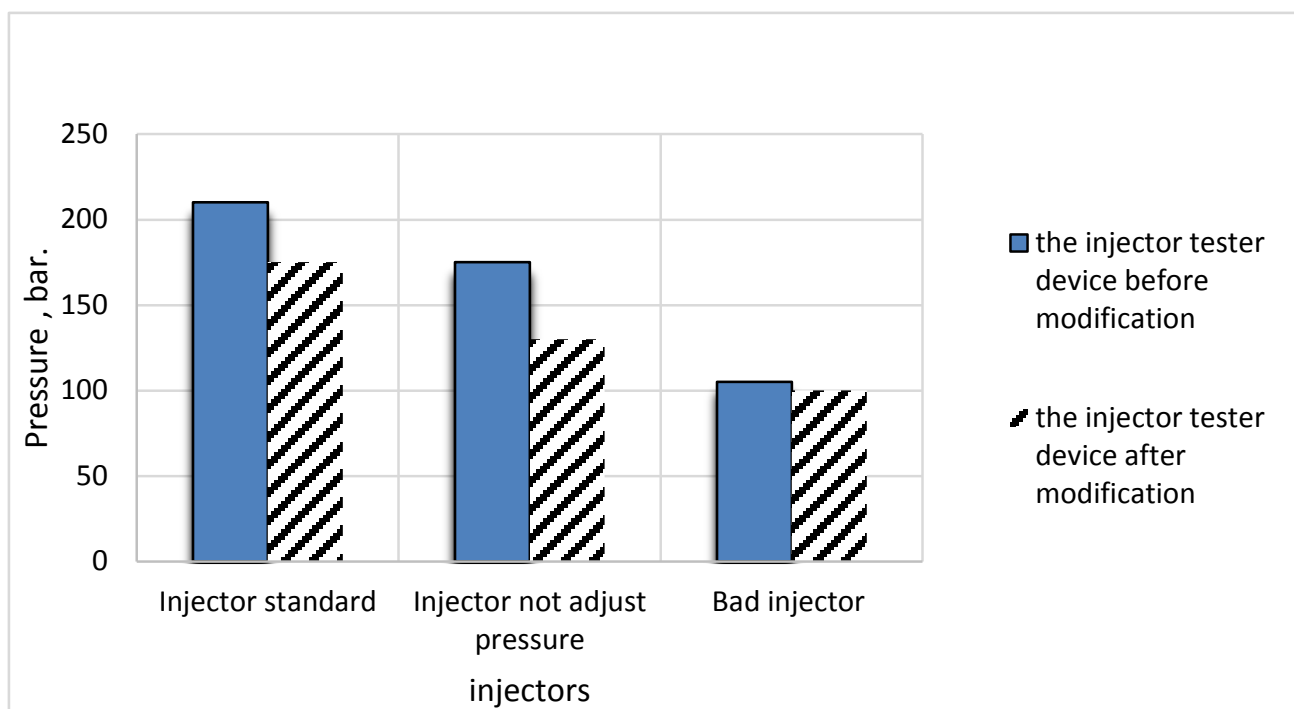

Fig. 6. Pressure with injector tester before and after modification

\section{CONCLUSION}

The mechanical injector tester was saving fuel more than manual injector tester. This is due to the regularity of the motion in the mechanical device but the manual device that is dependent on the operator and the irregularity of motion which cause irregularity of pressure. In addition, Glycerin manometer with the modified device was better than manual device. It has higher accuracy reading pressure than the manual manometer.

\section{REFERENCES}

Bashirnezhad, K., Moghiman, M., Amoli, M.J., Tofighi, F. and Zabetnia, S. 2008. Effect of fuel spary angle on soot formation in turbulent spray flames. World Academy of Sci. Engineering and Technology 2, 299-304.

Bell, B. 1995. Farm machinery. (4 ${ }^{\text {th }} E d$.) pp. 19-21. Farming Press Books. Miller Freeman Pofessional Ltd, UK.

Economic Affairs Sector, 2015. Agriculture Directorates \& Agric. Reform in the GovernoratesMinistry of Agric., Egypt. 
Heywood, J.B. 1988. Internal combustion engines fundamentals. pp. 526-530. Mc Graw Hill. Series in Mechanical Engineering, New York, USA.

Lechner, G.A., Jacobs, T.J., Chryssakis, C.A., Assanis, D.N. and Siewert, R.M. 2005. Evaluation of a narrow spray cone angle, advanced injection timing strategy to achieve partially premixed compression ignition combustion in a diesel engine Society of Automotive Engineers (No. 2005-01-0167), pp. 1-11.

Lee, C.S and Park, S.W. 2002. An experimental and numerical study on fuel atomization char acteristics of high-pressure diesel injection sprays. Fuel 81, 2417-2423.

Khair, M.K. and Jääskeläinen, H. 2013..Diesel fuel injection, www.dieselnet.com/tech/diesel fi.php.

Park, S.H., Cha, J. and Lee, C.S. 2011. Spray and engine performance characteristics of biodiesel and its blends with diesel and ethanol fuels. Combustion Sci. and Technology, 183(8), 802-822.

Svrcek, M.N., Miller, S.L. and Edwards, C.F. 2010. Diesel spray behavior at compression ratios up to 100:1. Atomization and Sprays, 20(5), 453-465. 